\title{
Influence of nickel and silicon addition on the deuterium siting and mobility in fcc Mg-Ti hydride studied with 2H MAS NMR.
}

\section{Citation for published version (APA):}

Manivasagam, T. G., Magusin, P. C. M. M., lliksu, M., \& Notten, P. H. L. (2014). Influence of nickel and silicon addition on the deuterium siting and mobility in fcc Mg-Ti hydride studied with $2 \mathrm{H}$ MAS NMR. Journal of Physical Chemistry C, 118(20), 10606-10615. https://doi.org/10.1021/jp500535q

DOI:

10.1021/jp500535q

Document status and date:

Published: 01/01/2014

\section{Document Version:}

Accepted manuscript including changes made at the peer-review stage

\section{Please check the document version of this publication:}

- A submitted manuscript is the version of the article upon submission and before peer-review. There can be important differences between the submitted version and the official published version of record. People interested in the research are advised to contact the author for the final version of the publication, or visit the $\mathrm{DOI}$ to the publisher's website.

- The final author version and the galley proof are versions of the publication after peer review.

- The final published version features the final layout of the paper including the volume, issue and page numbers.

Link to publication

\section{General rights}

Copyright and moral rights for the publications made accessible in the public portal are retained by the authors and/or other copyright owners and it is a condition of accessing publications that users recognise and abide by the legal requirements associated with these rights.

- Users may download and print one copy of any publication from the public portal for the purpose of private study or research.

- You may not further distribute the material or use it for any profit-making activity or commercial gain

- You may freely distribute the URL identifying the publication in the public portal.

If the publication is distributed under the terms of Article 25fa of the Dutch Copyright Act, indicated by the "Taverne" license above, please follow below link for the End User Agreement:

www.tue.nl/taverne

Take down policy

If you believe that this document breaches copyright please contact us at:

openaccess@tue.nl

providing details and we will investigate your claim. 


\title{
Electrochemical Deuteration of Metastable MgTi Alloys: An Effective Way to Inhibit Phase Segregation
}

\author{
Thirugnasambandam G. Manivasagam, Pieter C. M. M. Magusin, Subramanian \\ Srinivasan, Gopi Krishnan, Bart J. Kooi, and Peter H. L. Notten*
}

Hydrogen is considered to be a promising energy carrier for our future society as it is light-weight and has a high energy

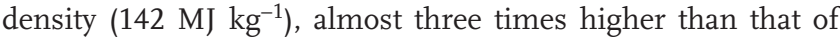
natural gas $\left(55 \mathrm{MJ} \mathrm{kg}^{-1}\right) \cdot{ }^{[1,2]}$ However, storing hydrogen in a safe and energy dense way is one of the remaining challenges. The volumetric density of hydrogen in metal hydrides is higher than that in alternative storing methods, such as liquid and compressed hydrogen. In addition, metal hydrides offer a relatively safe storage environment. ${ }^{[3-5]}$ Compared to conventional metal hydrides, such as $\mathrm{LaNi}_{5} \mathrm{H}_{x}, \mathrm{MgH}_{2}$ is a potentially attractive hydrogen-storage material because of its high gravimetric storage capacity amounting to $7.6 \mathrm{wt} \%$ of hydrogen. ${ }^{[2,4,6]}$ However, in its common rutile crystal structure $\mathrm{MgH}_{2}$ suffers from a poor (de)hydrogenation kinetics. In order to improve the thermodynamics and (de)sorption kinetics $\mathrm{MgH}_{2}$ can be modified in different ways, i.e., by forming nanoparticles, alloying $\mathrm{Mg}$ with transition metals and adding catalysts. ${ }^{[7-9]}$

Alloying Mg with a transition metal (TM), such as Sc, Ti, V, or Cr has a remarkable positive effect on the (de)hydrogenation kinetics. ${ }^{[9]}$ Well-mixed MgTM alloys with >20 at\% TM tend to adopt the fluorite structure after hydrogenation, ${ }^{[10-12]}$ which increases the hydrogen mobility significantly compared to that in rutile $\mathrm{MgH}_{2} \cdot{ }^{[13]}$ Due to its relatively high abundance and low atomic weight, $\mathrm{Ti}$ is particularly interesting as alloying element for large-scale applications. $\mathrm{Mg}$ and $\mathrm{Ti}$ have a positive mixing enthalpy and thus no thermodynamically stable alloys are formed. ${ }^{[14,15]}$ However, metastable alloys composed of $\mathrm{Mg}$ and Ti have been successfully synthesized in thin films by making use of advanced deposition techniques, such as co-sputtering, physical vapor- and electron-beam (e-beam) deposition. ${ }^{[9,16,17]}$

Although the results for thin films ${ }^{[18,19]}$ are scientifically interesting as a proof of principle, for large-scale applications bulk powders are much more expedient because of the readily available synthesis and processing routes. For economically feasible large-scale production of powders mechanical alloying is a proven method. Ball-milling has been successfully employed

T. G. Manivasagam, Dr. P. C. M. M. Magusin,

Dr. S. Srinivasan, Prof. P. H. L. Notten

Department of Chemical Engineering and Chemistry

Eindhoven University of Technology

Postbus 513, 5600, MB Eindhoven, The Netherlands

E-mail: p.h.l.notten@tue.nl

Dr. G. Krishnan, Prof. B. J. Kooi

Zernike Institute of Advanced Materials

University of Groningen

9747, AG, Groningen, The Netherlands for the preparation of metastable Mg-Ti powders. ${ }^{[20-22]}$ Hydrogenation of Mg-Ti alloys can be achieved either via the gas phase at elevated temperatures or via electrochemical reduction in hydrogen/deuterium donating electrolytes at room temperature. Disadvantageously, the elevated temperatures required for $\mathrm{H}_{2}$ gas ab- and desorption induce phase segregation in these metastable alloys. ${ }^{[23,24]}$ In contrast, electrochemical hydrogenation of thin $\mathrm{Mg}_{1-x} \mathrm{Ti}_{x}$ films can be achieved at room temperature without phase segregation and yields a single-phase fluoritestructured compound with favorable materials properties. ${ }^{[25]}$ However, the phase stability of the mechanically prepared $\mathrm{Mg}_{1-x} \mathrm{Ti}_{x}$ powders during low temperature electrochemical (de) hydrogenation is yet unclear. To the best of our knowledge, this is the first report which shows that the phase segregation of ball-milled powders can be prevented by electrochemical deuteration instead of gas-phase deuteration.

Here we report a magic-angle spinning (MAS) ${ }^{2} \mathrm{H}$ NMR study on electrochemically deuterated $\mathrm{Mg}$-Ti electrodes at room temperature, leading to the conclusion that phase segregation does not occur under these low temperature conditions. The chemical resolution in ${ }^{2} \mathrm{H}$ NMR spectra of metal deuterides tends to be higher than in ${ }^{1} \mathrm{H}$ NMR spectra of the corresponding metal hydrides. ${ }^{[13,26,27]}$ In the present study $\mathrm{Mg}_{0.65} \mathrm{Ti}_{0.35}$ was prepared by means of $28 \mathrm{~h}$ ball-milling. Subsequently, Pd was added to the homogenous alloy and ball-milling was continued for 90 min in order to create a 5 at\% Pd coating at the surface of the $\mathrm{Mg}_{0.65} \mathrm{Ti}_{0.35}$ particles. Pd is an essential catalyst to provide excellent electrochemical hydrogenation properties. ${ }^{[28,29]}$ It also protects the underlying alloy from oxidation.

Electrochemical deuterium loading, also denoted here as charging, was carried out in a conventional three-electrode electrochemical cell, which was thermostated at $25{ }^{\circ} \mathrm{C}$, using alkaline $\mathrm{D}_{2} \mathrm{O}$ as electrolyte (Figure 1a). The cell consisted of a metal deuteride (MD) working electrode containing the $\mathrm{Mg}_{0.65} \mathrm{Ti}_{0.35} \mathrm{D}_{x}$ alloy along with silver or carbon black as additive, a Pd counter electrode and a $\mathrm{Hg} / \mathrm{HgO}$ reference electrode. All electrode potentials are referring to this reference electrode. Charging of the working electrode is initiated by electrochemical reduction of $\mathrm{D}_{2} \mathrm{O}$ according to

$\mathrm{M}+\mathrm{D}_{2} \mathrm{O}+\mathrm{e}^{-} \leftrightarrow \mathrm{MD}_{\mathrm{ad}}+\mathrm{OD}^{-}$

resulting in the adsorption of deuterium atoms $\left(\mathrm{MD}_{\mathrm{ad}}\right)$ at the electrode surface. Subsequently, the adsorbed deuterium atoms diffuse into the bulk of the electrode, forming a metal deuteride. Two neighboring deuterium atoms adsorbed at the electrode surface can also recombine to $D_{2}$, which is released from the electrode surface as a gas. Obviously, this parasitic

DOI: 10.1002/aenm.201300590 
(a)

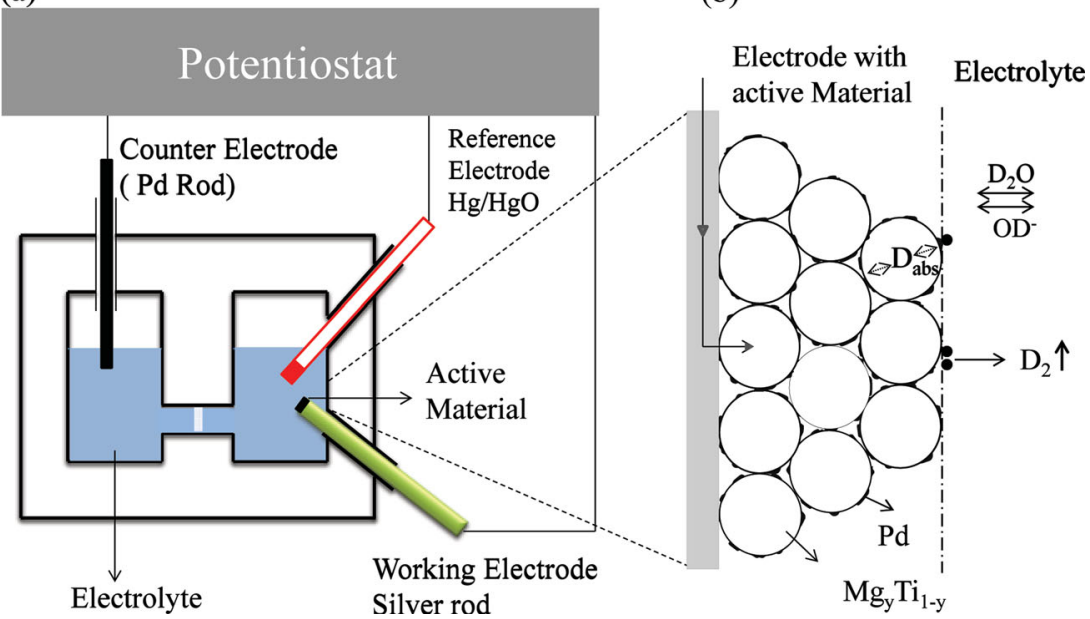

Figure 1. a) Three electrode electrochemical setup used for the deuteration process. b) Schematic representation at a higher magnification of a powder electrode made of $\mathrm{Mg}_{0.65} \mathrm{Ti}_{0.35}$ powder particles with $\mathrm{Pd}$ on top of the powder in contact with the strong alkaline electrolyte (6 $\mathrm{M}$ potassium hydroxide in $\mathrm{D}_{2} \mathrm{O}$ )

reaction competes with the deuteride-forming reaction. The absorbed deuterium can also be oxidized during electrochemical discharging.

Powder electrodes, made with silver as conducting material, resulted in mechanically stable electrodes, revealing welldefined voltage plateaus and low electrochemical over-potentials. From an electrochemical point of view this electrode configuration is therefore preferred. However, the use of silver (heavy and highly conductive) causes unstable sample rotation and radio-frequency skin depth problems in MAS NMR. To overcome these problems carbon black (CB) was used as additive instead of Ag. This electrode configuration was found to be excellent for the NMR measurements. The constant-current charging (Figure 2A, curve a) of the $\mathrm{Mg}_{0.65} \mathrm{Ti}_{0.35} / \mathrm{Ag}$ electrode clearly exhibits three voltage plateaus. The first two can be attributed to the deuteration of $\mathrm{Ti}$ and $\mathrm{Mg}$, respectively.

After the deuteration is complete, the voltage saturates at more negative potentials where $\mathrm{D}_{2}$ gas evolution becomes visible at the electrode. The amount of deuterium absorbed in the material can be calculated from the transition between the second and third voltage plateau. This position is defined by the gravimetric capacity where the voltage derivative is at maximum (Figure 2B). The amount of deuterium absorbed in $\mathrm{Mg}_{0.65} \mathrm{Ti}_{0.35^{-}}$ deuteride is equivalent to $825 \mathrm{mAh} \mathrm{g}^{-1}$. Since the formation of deuterons involves 1 electron per atom (Equation (1), the electrochemical charge capacity $Q\left(\mathrm{mAh} \mathrm{g}^{-1}\right)$ can be converted into a deuterium weight fraction $v_{\mathrm{D}}$ (wt\%), according to

$v_{\mathrm{D}}=360 \frac{Q}{F} M_{\mathrm{D}}$

where $F$ is Faraday's constant $\left(9.65 \times 10^{4} \mathrm{C} \mathrm{mol}^{-1}\right)$ and $M_{\mathrm{D}}$ is the molar mass of deuterium $\left(2.01 \mathrm{~g} \mathrm{~mol}^{-1}\right)$. Thus, the deuterium storage capacity of $\mathrm{Mg}_{0.65} \mathrm{Ti}_{0.35}$ in the present study corresponds to $6.2 \mathrm{wt} \% \mathrm{D}$. This is equivalent to overall composition $\mathrm{Mg}_{0.65} \mathrm{Ti}_{0.35} \mathrm{D}_{1.12}$. Curve $\mathrm{b}$ of Figure $2 \mathrm{~A}$ shows the result of the same experiment but now with a $\mathrm{Mg}_{0.65} \mathrm{Ti}_{0.35} / \mathrm{CB}$ electrode.
Since the electrode voltages are more negative in this case, the charge transfer kinetics is poorer than for the electrode with Ag. As a result of the higher overpotentials the distinction between the plateaus has vanished. However, the purpose of this experiment is not to investigate the electrochemistry of the deuteration reaction in detail, but to electrochemically deuterate the metastable $\mathrm{Mg}_{0.65} \mathrm{Ti}_{0.35}$ alloy, and characterize its nanostructure and deuterium mobility with NMR afterwards. To check whether the $\mathrm{Mg}_{0.65} \mathrm{Ti}_{0.35} /$ CB has indeed absorbed deuterium, the electrode was discharged in two current steps, i.e. with a high and low current (curves $\mathrm{C}$ and $d$, respectively in Figure 2A), until the cut-off voltage of $0 \mathrm{~V}$ vs the $\mathrm{Hg} / \mathrm{HgO}$ reference electrode had been reached. The total charge extracted from the electrode was $630 \mathrm{mAh} \mathrm{g}^{-1}$. This is in good agreement with the extracted charge $\left(600 \mathrm{mAh} \mathrm{g}^{-1}\right)$ measured for the Ag electrode. The extracted charge is smaller than the loaded charge which is likely due to the stronger fixation of deuterium in $\mathrm{TiD}_{2}$ nanodomains than the $\mathrm{MgD}_{2}$ nanodomains. The non-extracted deuterium is strongly bound in $\mathrm{TiD}_{2}$ nanodomains. Evidence for this is that the formation enthalpy of $\mathrm{TiH}_{2}\left(144 \mathrm{~kJ} \mathrm{~mol}^{-1}\right)$ is much higher than that of $\mathrm{MgH}_{2}\left(77 \mathrm{~kJ} \mathrm{~mol}^{-1}\right)$.

Selected area electron diffraction (SAED) of electrochemically deuterated $\mathrm{Mg}_{0.65} \mathrm{Ti}_{0.35} \mathrm{D}_{1.12}$ (Figure $2 \mathrm{C}$ ) shows three reflections corresponding to d-spacing values of $4.78,2.75$ and $2.38 \AA$. This suggests close similarity to the $\mathrm{Ca}_{7} \mathrm{Ge}$-type fcc super structure reported for the high-pressure phase of $\mathrm{Mg}_{7} \mathrm{TiH}_{\mathrm{x}}{ }^{[30]}$ these corresponding reflections have been labeled 200, 222, and 400. The d-spacing derived from the strongest 222 reflection $(2.38 \AA$ ) is close to the reported value from the 111 reflection observed for $\mathrm{Mg}_{0.70} \mathrm{Ti}_{0.30} \mathrm{H}_{x}$ thin films, for which a simple fcc structure was assumed. ${ }^{[16]}$

The nanostructure of $\mathrm{Mg}_{0.65} \mathrm{Ti}_{0.35} \mathrm{D}_{1.12}$ was further investigated with ${ }^{2} \mathrm{H}$ NMR (Figure 3). In order to fully understand the NMR spectra of this complex material also NMR spectra of the separate elemental metal hydrides have been investigated. Moreover, spectra were recorded for both electrochemical or gas-phase deuterated samples, which will be distinguished below by the superscripts (e) or (g), respectively. Magic angle spinning (MAS) increases the chemical resolution in the ${ }^{2} \mathrm{H}$ NMR spectra by removing the quadrupolar line broadening. The spinning sideband patterns, which are visible at moderate sample rotation rates, reflect the deuterium-coordination symmetry in the respective crystal structures. The ${ }^{2} \mathrm{H}$ NMR spectrum of $\mathrm{MgD}_{2}{ }^{(\mathrm{g})}$ exhibits an extensive sideband pattern over a wide frequency range (Figure 3a). This is consistent with the threefold coordination of deuterium by $\mathrm{Mg}$ atoms in rutile $\mathrm{MgD}_{2} \cdot{ }^{[31]}$ In contrast, $\mathrm{TiD}_{2}$ has a fluorite structure with deuterium atoms located at tetrahedral interstitial sites. The high coordination symmetry results in weak sidebands surrounding the centerband at $-150 \mathrm{ppm}$ for gas-phase deuterated $\mathrm{TiD}_{2}{ }^{(\mathrm{g})}$ (Figure 3d). The large, negative Knight shift for $\mathrm{TiD}_{2}{ }^{(\mathrm{g})}$ is typical for the conductive bulk material. 


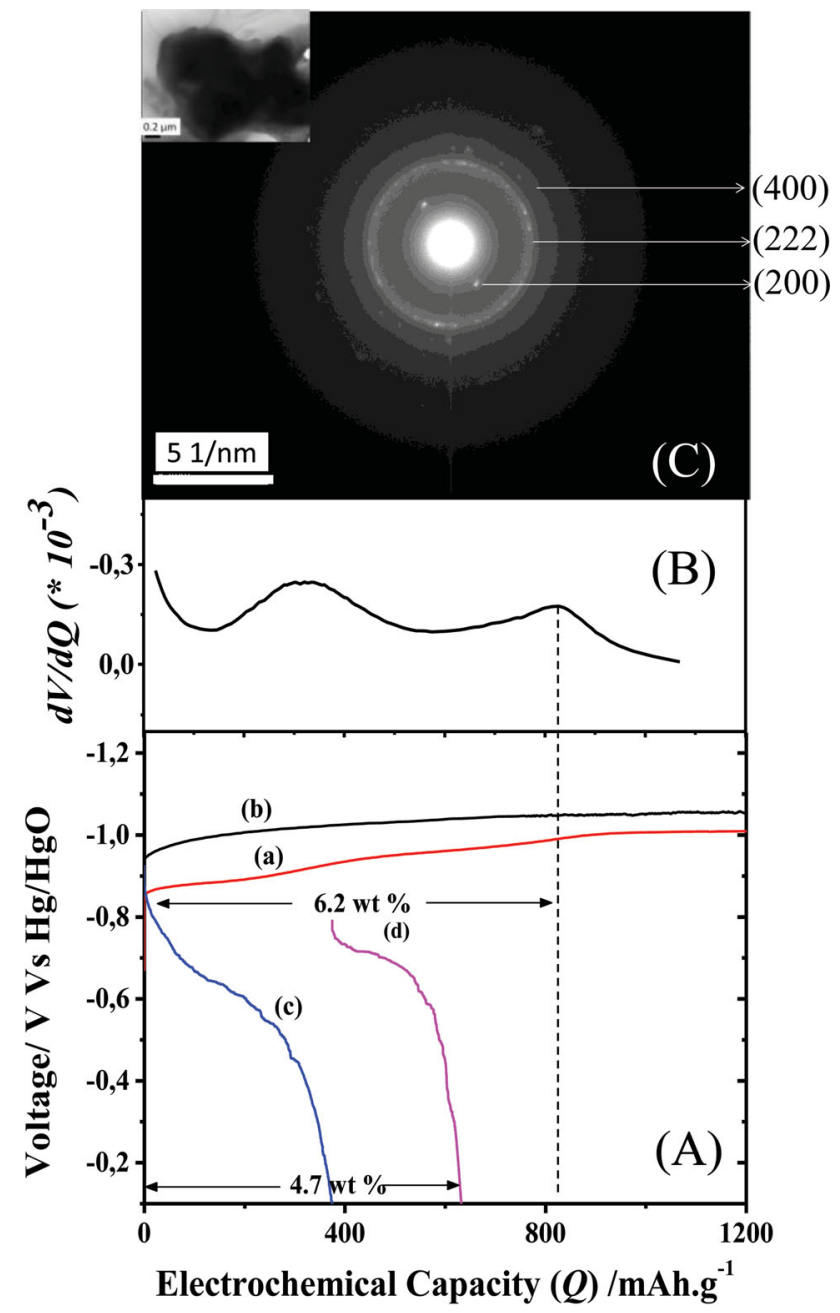

Figure 2. A) Electrochemical deuteration $(50 \mathrm{~mA} / \mathrm{g})$ of a $\mathrm{Mg}_{0.65} \mathrm{Ti}_{0.35}$ powder electrode pressed with silver (a) and carbon black (b) as additive. High-current $(50 \mathrm{~mA} / \mathrm{g})$ (c) and low-current $(10 \mathrm{~mA} / \mathrm{g})$ (d) discharging of the $\mathrm{Mg}_{0.65} \mathrm{Ti}_{0.35}$ /carbon black electrode. Low-current discharging is performed to extract the maximum amount of deuterium stored in the electrode. The discharge capacities mentioned in text is the summation of the high- and low-current discharge capacities. B) Derivative of voltage with respect to capacity versus capacity. C) SAED patterns of electrochemically deuterated $\mathrm{Mg}_{0.65} \mathrm{Ti}_{0.35} \mathrm{D}_{1.12}$ with reflections of the $\mathrm{Ca}_{7} \mathrm{Ce}$-type fcc super structure indicated and the corresponding plan-view TEM images of a selected particle (inside).

Figure $3 \mathrm{~b}$ shows the ${ }^{2} \mathrm{H}$ NMR spectrum of electrochemically deuterated $\mathrm{Mg}_{0.65} \mathrm{Ti}_{0.35} \mathrm{D}_{1.12}{ }^{(\mathrm{e})}$. The overall deuterium content estimated from the total spectral integral, $5.7 \mathrm{wt} \%$, is in good agreement with the electrochemically determined content. The fact that no typical bulk $\mathrm{TiD}_{2}$ signal is present at $-150 \mathrm{ppm}$ (Figure 3d) shows that no strong phase segregation takes places during electrochemical deuteration. Instead, the signal at approximately $-70 \mathrm{ppm}$ signifies $\mathrm{TiD}_{2}$ nanodomains similar to that of co-sputtered $\mathrm{Mg}_{0.65} \mathrm{Ti}_{0.35} \mathrm{D}_{1.1} \cdot{ }^{[31]} \mathrm{As}$ is the case for pure $\mathrm{MgD}_{2}{ }^{(\mathrm{g})}$ there is a centerband signal at $\approx 4 \mathrm{ppm}$, which is therefore assigned to $\mathrm{MgD}_{2}$ nanodomains. However, the corresponding sideband pattern extends over a less broad range than that of the pure $\mathrm{MgD}_{2}{ }^{(\mathrm{g})}$ (Figure 3a), and is very

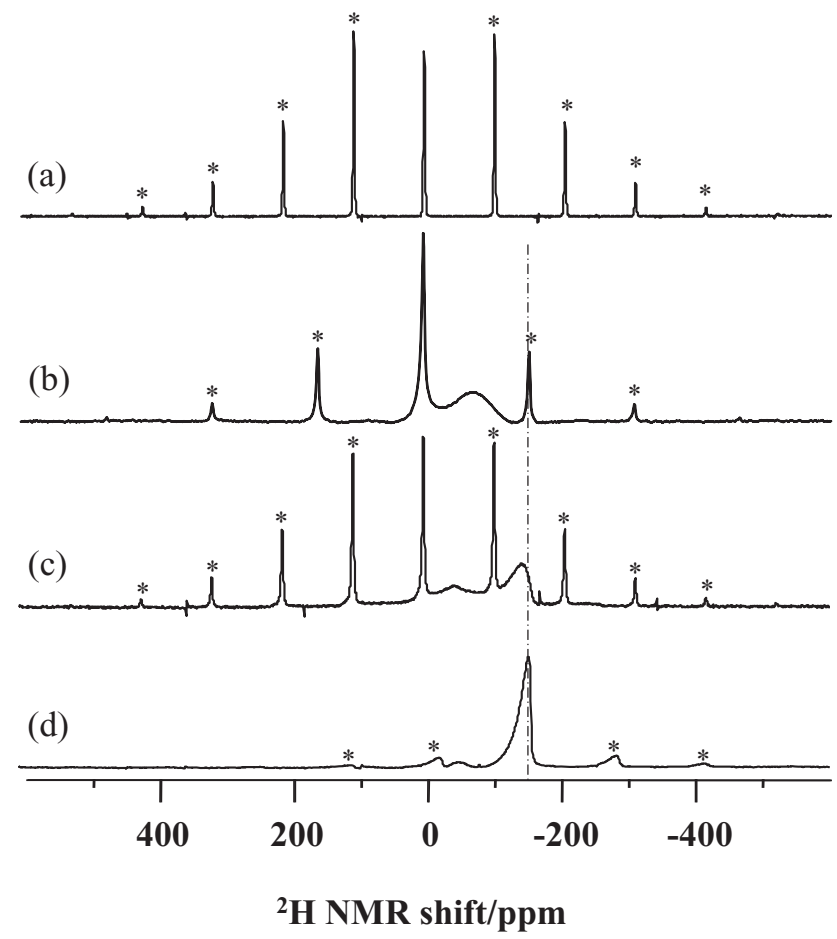

Figure 3. ${ }^{2} \mathrm{H}$ NMR spectra of a) $\operatorname{MgD}_{2}{ }^{(g)}$, b) $M_{0.65} \mathrm{Ti}_{0.35} \mathrm{D}_{1.12}{ }^{(\mathrm{e})}$ c) $\mathrm{Mg}_{0.65} \mathrm{Ti}_{0.35} \mathrm{D}_{0.65}{ }^{(\mathrm{g})}$ and d) $\mathrm{TiD}_{2}{ }^{(\mathrm{g})}$. Samples indexed with (e) were electrochemically deuterated with a current density of $50 \mathrm{~mA} \mathrm{~g}^{-1}$ at $25^{\circ} \mathrm{C}$. Samples indexed with (g) were deuterated via the gas phase at $175^{\circ} \mathrm{C}$ under 75 bar. Spinning sidebands are marked with *. Sample rotation rates were between 8 and $12.5 \mathrm{kHz}$.

similar to that of the melt-cast $\mathrm{Mg}_{0.65} \mathrm{Sc}_{0.35} \mathrm{D}_{2.2}$ and co-sputtered $\mathrm{Mg}_{0.65} \mathrm{Ti}_{0.35} \mathrm{D}_{1.1}$ reported before. ${ }^{[31,32]}$ The latter two materials were shown to have a single-phase fluorite structure with the deuterium atoms at tetrahedral positions. Indeed, the tetrahedral coordination of deuterium in the fluorite structure leads to weaker spinning sidebands than the threefold coordination in rutile $\mathrm{MgD}_{2}$. Unlike in $\mathrm{fcc} \mathrm{TiD}_{2}$, however, deuterium atoms in fcc $\mathrm{Mg}_{0.65} \mathrm{Ti}_{0.35}$ may well have mixed $(\mathrm{Mg}, \mathrm{Ti})$ coordination, or the fcc crystal structure may be otherwise distorted by the co-presence of $\mathrm{Mg}$ and Ti. The resulting symmetry distortion is reflected by the spinning sidebands stronger than those for $\mathrm{TiD}_{2}{ }^{(\mathrm{g})}$ (Figure 3d).

In contrast to the $\mathrm{Mg}_{0.65} \mathrm{Ti}_{0.35} \mathrm{D}_{1.12}{ }^{(\mathrm{e})}$, the sideband pattern of $\mathrm{Mg}_{0.65} \mathrm{Ti}_{0.35} \mathrm{D}_{0.65} \mathrm{~g}$ (Figure 3c) is similar to that of rutile $\mathrm{MgD}_{2}{ }^{\text {(g) }}$ (Figure 3a). The spectrum also reveals a signal at the bulk $\mathrm{TiD}_{2}$ position $-150 \mathrm{ppm}$, similar to $\mathrm{TiD}_{2}{ }^{(\mathrm{g})}$ (Figure $3 \mathrm{~d}$ ). In addition there is a third signal at $-43 \mathrm{ppm}$, which has been earlier assigned to $\mathrm{TiD}_{1.5}$ nanodomains in close contact with the $\mathrm{MgD}_{2}$ phase. High temperature gas phase loading of $\mathrm{Mg}_{0.65} \mathrm{Ti}_{0.35} \mathrm{D}_{0.65}{ }^{(\mathrm{g})}$ induces partial phase segregation into rutile $\mathrm{MgD}_{2}$ nanodomains with interdispersed $\mathrm{TiD}_{1.5}$ layers and a separate $\mathrm{fcc} \mathrm{TiD}_{2}$ phase. This phase segregation was also confirmed by Neutron diffraction and XRD. ${ }^{[23]}$

The ${ }^{2} \mathrm{H}$ NMR spectrum of $\mathrm{Mg}_{0.65} \mathrm{Ti}_{0.35} \mathrm{D}_{1.12}{ }^{(\mathrm{e})}$ can be decomposed into four overlapping line shape components, positioned at 7, 4, -30 and $-73 \mathrm{ppm}$ (Figure 4a). Only the $4 \mathrm{ppm}$ component has spinning sidebands, which helps to define 


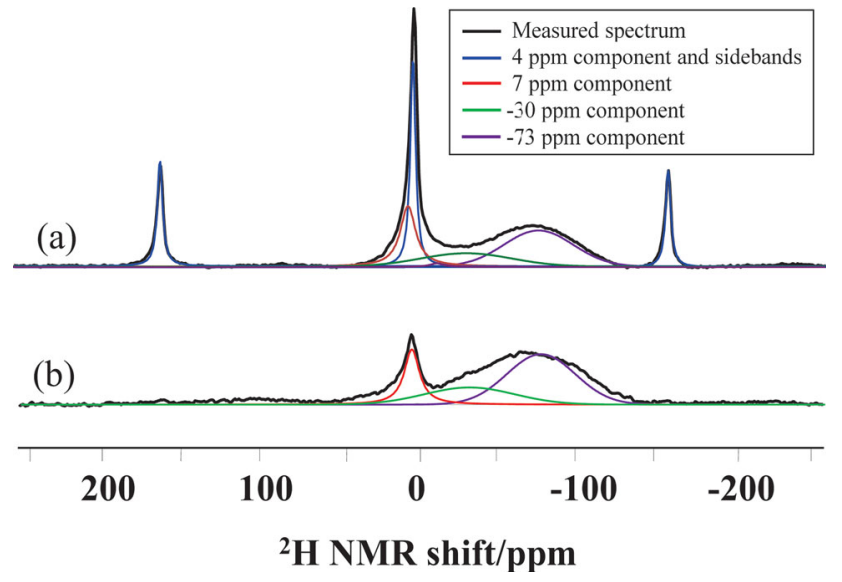

Figure 4. ${ }^{2} \mathrm{H}$ NMR spectra of $\mathrm{Mg}_{0.65} \mathrm{Ti}_{0.35} \mathrm{D}_{1.12}$ (e) ball-milled and electrochemically charged (a) and after electrochemical low current discharging (b).

its lineshape in the centerband as well. Both signals at 4 and $7 \mathrm{ppm}$ are assigned to deuterium with tetrahedral $\mathrm{Mgn}_{\mathrm{n}} \mathrm{Ti}_{4-\mathrm{n}}$ coordination in Mg-rich nanodomains. The components at -30 and $-73 \mathrm{ppm}$ are comparable to those attributed to the Ti-rich nanodomains found in co-sputtered $\mathrm{Mg}_{0.65} \mathrm{Ti}_{0.35} \mathrm{D}_{1.1} \cdot{ }^{[31]}$ Electrochemically discharging has a remarkable effect on the component distribution as Figure $4 \mathrm{~b}$ shows. The intense 4 ppm component and its accompanying side-bands are now completely absent whereas the $7,-30$ and -73 ppm components are more or less unaffected. Apparently, the intense $4 \mathrm{ppm}$ component with its sidebands can be entirely correlated to the reversible deuterium stored in $\mathrm{Mg}_{0.65} \mathrm{Ti}_{0.35} \mathrm{D}_{1.12}{ }^{(\mathrm{e})}$. The other, less intense, components must then be related to the strongly bound deuterium staying behind in the discharged material.

Using 2D exchange NMR spectroscopy we have studied the deuterium mobility between Mg-rich and Ti-rich sites. More precisely, 2D Exsy correlates the chemical shift of deuterium atoms before and after a selected mixing time interval $t_{\text {mix }}$, during which the deuterium atoms have the chance to move between different sites. Deuterium atoms which are stably bound or deeply buried within a separate phase do not undergo a chemical-shift change during $t_{\text {mix }}$ and will give rise to peaks at the spectral diagonal only. In contrast, deuterium atoms which exchange between, e.g. Mg-rich and Ti-rich sites during $t_{\text {mix }}$ will change their chemical shift, which shows up as off-diagonal "cross-peaks" in the 2D spectrum. For $t_{\text {mix }}=0.01 \mathrm{~s}$ (Figure 5a) only peak intensity along the diagonal appears, indicating that no deuterium exchange occurs at this timescale. For $t_{\text {mix }}=2 \mathrm{~s}$, cross-peaks are observed (Figure $5 b$ ), indicating extensive deuterium exchange between Mg-rich and Ti-rich sites. A measure for the "unrestrictedness" of the exchange is the similarity between projections $\mathrm{P}$ and cross-sections $\mathrm{S}$ as plotted above the 2D spectra in Figure 5a,b. The projections reflect the deuterium distribution over the various sites, while the particular crosssections shown in Figure 5 indicate how deuterium atoms, which were initially located in Mg-rich domains, become redistributed during the mixing time. For $t_{\text {mix }}=2 \mathrm{~s}$ the cross-section is similar to the projection. Thus, at this timescale deuterium has become evenly redistributed over all sites. The fact that

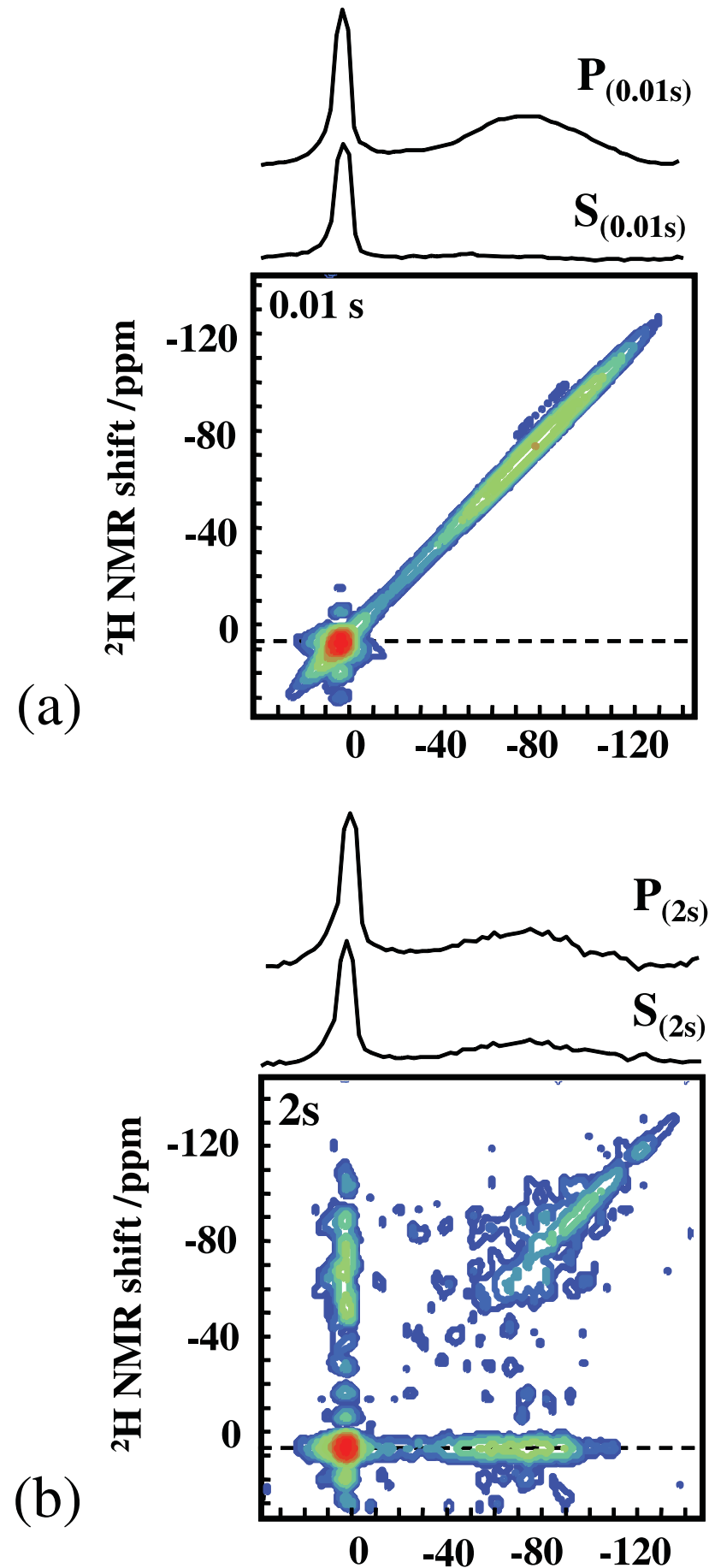

${ }^{2} \mathrm{H}$ NMR Shift /ppm

Figure 5. 2D exchange spectra with mixing time $t_{\text {mix }}$ of a) $0.01 \mathrm{~s}$ and b) $2 \mathrm{~s}$. Projections $\mathrm{P}$ and cross-sections $\mathrm{S}$ for $\delta_{1}=4 \mathrm{ppm}$ are shown above the $2 \mathrm{D}$ spectra. $\mathrm{P}$ illustrates the overall deuterium distribution, while $\mathrm{S}$ the redistribution of deuterium initially at $\mathrm{Mg}$-rich sites.

this occurs in seconds proves that no macrophase segregation occurs in the electrochemically deuterated alloy.

The exchange between Mg-rich and Ti-rich sites was studied systematically as a function of mixing time with one-dimensional 
(a)

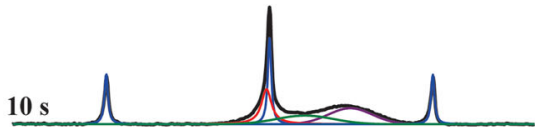

)
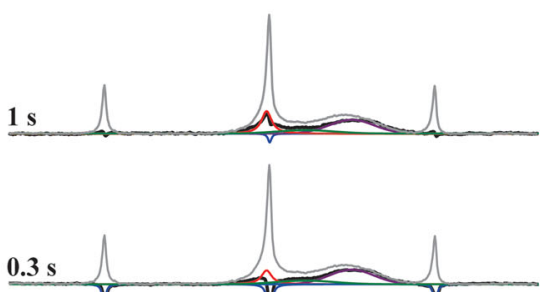

(b)
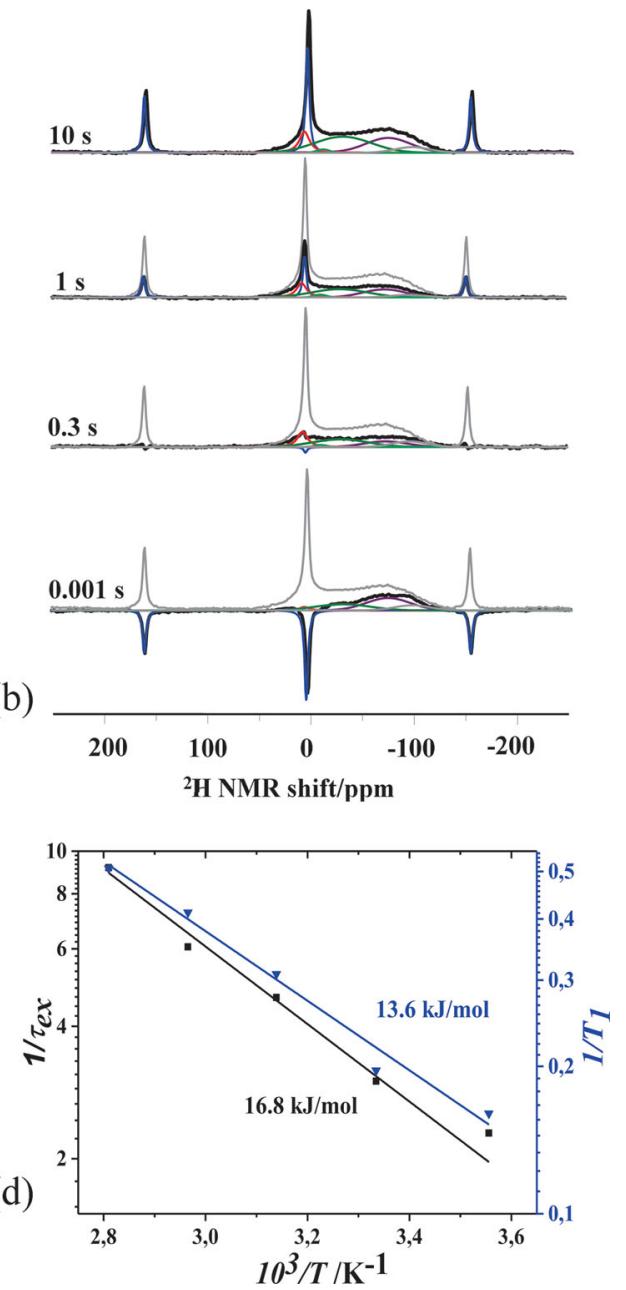

Figure 6. a,b) 1D Exsy spectra of electrochemically deuterated $\mathrm{Mg}_{0.65} \mathrm{Ti}_{0.35} \mathrm{D}_{1.12}{ }^{\text {(e) }}$ at various mixing times: $0.001,0.3,1,10 \mathrm{~s}$. For comparison, the fully relaxed spectrum after $10 \mathrm{~s}$ mixing time is also shown (grey curves) at $280 \mathrm{~K}$ (a) and $355 \mathrm{~K}$ (b). c) Peak areas $I_{\mathrm{Mg}}$ (squares) and $I_{\mathrm{Ti}}$ (circles) as a function of mixing time $t_{\text {mix }}$ together with the total intensity $I_{\text {tot }}$ (triangles). The continuous curves are based on a least-square fit of the coupled bi-exponential model described by Equation 2. d) Arrhenius plot of the effective deuterium exchange rate $\tau_{\text {ex }}{ }^{-1}$ extracted from the coupled bi-exponential fit of $I_{\mathrm{Mg}}\left(t_{\mathrm{mix}}\right)$ and $I_{\mathrm{Ti}}\left(t_{\mathrm{mix}}\right)$ at various temperature (squares) and $1 / T_{1}$ extracted from the inversion recovery experiments (inverted triangles).

exchange spectroscopy. Our 1D exchange experiments involve selective polarization inversion of deuterium spins at the Mgrich sites followed by a varied mixing time $t_{\text {mix }}$. Deuterium atoms with perturbed polarization initially at Mg-rich sites will replace unperturbed deuterium at the Ti-rich sites and vice versa. As a result, the signal intensity of the originally nonperturbed sites will decrease, and that of the initially perturbed sites will increase as function of $t_{\text {mix }}$ (see Figure $\left.6 a, b\right)$. Figure $6 c$ illustrates the development of the intensity $I_{\mathrm{Mg}}$ of the $4 \mathrm{ppm}$ component combined with its sidebands, and $I_{\mathrm{Ti}}$ of the combined -30 and $-73 \mathrm{ppm}$ components versus $t_{\text {mix }}$ at $280 \mathrm{~K}$. $I_{\mathrm{Mg}}$ shows a two-step increase, whereas $I_{\mathrm{Ti}}$ initially decreases and then increases. The combined behavior of $I_{\mathrm{Mg}}\left(t_{\text {mix }}\right)$ and $I_{\mathrm{Ti}}\left(t_{\text {mix }}\right)$ is well described by a coupled bi-exponential model ${ }^{[31]}$

$$
\begin{aligned}
I_{\mathrm{Mg}}\left(t_{\text {mix }}\right) & =\left\{I_{\mathrm{Mg}}(0)-I_{\mathrm{Mg}}^{\infty}\right\} \exp \left(-t_{\text {mix }} / \tau_{\mathrm{ex}}\right) \\
& +\left(I_{\mathrm{Mg}}^{\infty}-I_{\mathrm{Mg}}^{\mathrm{eq}}\right) \exp \left(-t_{\text {mix }} / T_{1}\right)+I_{\mathrm{Mg}}^{\mathrm{eq}}
\end{aligned}
$$

$$
\begin{aligned}
I_{\mathrm{Ti}}\left(t_{\text {mix }}\right) & =\left\{I_{\mathrm{Ti}}(0)-I_{\mathrm{Ti}}^{\infty}\right\} \exp \left(-t_{\text {mix }} / \tau_{\mathrm{ex}}\right) \\
& +\left(I_{\mathrm{Ti}}^{\infty}-I_{\mathrm{Ti}}^{\mathrm{eq}^{\mathrm{q}}}\right) \exp \left(-t_{\text {mix }} / T_{1}\right)+I_{\mathrm{Ti}}^{\mathrm{eq}}
\end{aligned}
$$

where the thermal-equilibrium intensities $\left(I_{\mathrm{Mg}}^{\mathrm{eq}}\right.$ and $\left.I_{\mathrm{Ti}}^{\mathrm{eq}}\right)$ are proportional to the respective densities of $\mathrm{Mg}$ - and Ti-rich sites, and $I_{\mathrm{Mg}}^{\infty}=\left\{I_{\mathrm{Mg}}(0)+I_{\mathrm{Ti}}(0)\right\} I_{\mathrm{Mg}}^{\mathrm{eq}} /\left(I_{\mathrm{Mg}}^{\mathrm{eq}}+I_{\mathrm{Ti}}^{\mathrm{eq}}\right)$ and $I_{\mathrm{Ti}}^{\infty}=$ $\left\{I_{\mathrm{Mg}}(0)+I_{\mathrm{Ti}}(0)\right\} I_{\mathrm{Ti}}^{\mathrm{eq}} /\left(I_{\mathrm{Mg}}^{\mathrm{eq}}+I_{\mathrm{Ti}}^{\mathrm{eq}}\right)$ are the signal intensities in the intermediate state, when the combined initial polarization $I_{\mathrm{Mg}}(0)+I_{\mathrm{Ti}}(0)$ is homogeneously distributed over the Mg- and Ti-rich sites by deuterium exchange. Herewith it is assumed that the deuterium exchange is fast compared to the spin-lattice relaxation $\left(\tau_{\mathrm{ex}}<T_{1}\right)$ and averages out any intrinsic $T_{1}$ differences between deuteriums at Mg- and Ti-rich sites. The spin-lattice relaxation times $\left(T_{1}\right)$ can also be independently determined by making use of inversion-recovery relaxometry. The obtained relaxation times nicely match the $T_{1 z}$ values extracted from the 1D Exsy curves at the corresponding temperatures. 
To estimate the activation barrier for deuterium mobility in $\mathrm{Mg}_{0.65} \mathrm{Ti}_{0.35} \mathrm{D}_{1.12}{ }^{(\mathrm{e})}$, $1 \mathrm{D}$ Exsy was carried out at various temperatures. The observed deuterium exchange becomes faster with increasing temperature. For instance, the zero crossing of the initially inverted 4-ppm signal during the recovery process occurs earlier at $355 \mathrm{~K}$ (Figure 6b) than at $280 \mathrm{~K}$ (Figure 6a). Such temperature trend is indeed to be expected for chemical exchange of deuterons between different sites. In principle, polarization exchange between deuterium spins could also give rise to cross-correlation in 1D and 2D Exsy. However, such ${ }^{2} \mathrm{H}-{ }^{2} \mathrm{H}$ spin diffusion would essentially be temperature independent. The observed exchange in 1D and 2D Exsy is indeed dominated by deuterium mobility. From 280 to $355 \mathrm{~K}$, the effective deuterium residence time $\tau_{\mathrm{ex}}$ in $\mathrm{Mg}$ - and Ti-rich nanodomains decreases from 0.48 to $0.10 \mathrm{~s}$ (Figure 6d), which corresponds to an activation energy of $16.8 \mathrm{~kJ} \mathrm{~mol}^{-1}$, comparable to the barrier energy estimated from the 1D Exsy of co-sputtered $\mathrm{Mg}_{0.65} \mathrm{Ti}_{0.35} \mathrm{D}_{1.1} \cdot{ }^{[31]}$

The $T_{1}$ values extracted from the 1D Exsy curves also contain information about deuterium mobility. In contrast to $\tau_{\mathrm{ex}}$, directly reflecting deuterium exchange between the NMR -distinguishable $\mathrm{Mg}$ - and Ti-rich sites, $T_{1}$ is an indirect measure for the correlation time $\tau_{\mathrm{c}}$ of deuterium exchange between any neighboring sites. The overall $T_{1}$ relaxation is the weighted average between the intrinsic relaxation at the Mg-rich sites controlled by quadrupolar-coupling fluctuations, and the intrinsic relaxation at the Ti-rich sites controlled by Knight-shift fluctuations ${ }^{[33]}$

$\frac{1}{T_{1}^{\mathrm{Mg}}}=\frac{2}{3}\left\langle\Delta \omega_{\mathrm{Q}}^{2}\right\rangle\left(\frac{\tau_{\mathrm{c}}}{1+\omega_{0}^{2} \tau_{\mathrm{c}}^{2}}+\frac{4 \tau_{\mathrm{c}}}{1+4 \omega_{0}^{2} \tau_{\mathrm{c}}^{2}}\right)$

$\frac{1}{T_{1}^{T i}}=\frac{1}{15}\left\langle\Delta \omega_{K S}^{2}\right\rangle \frac{\tau_{c}}{1+\omega_{0}^{2} \tau_{c}^{2}}$

where $\left\langle\Delta \omega_{\mathrm{Q}}^{2}\right\rangle$ and $\left\langle\Delta \omega_{\mathrm{KS}}^{2}\right\rangle$ represent the average size of the quadrupolar-coupling and Knight-shift fluctuations, respectively, $\omega_{0}$ the ${ }^{2} \mathrm{H}$ NMR frequency and $\tau_{\mathrm{c}}$ the motion correlation time. For very fast deuterium mobility $\left(\omega_{0} \tau_{\mathrm{c}}<<1\right), T_{1}$ is inversely proportional to $\tau_{\mathrm{c}}$, whereas for less fast mobility $\left(\omega_{0} \tau_{\mathrm{c}} \gg 1\right), T_{1}$ is directly proportional to $\tau_{\mathrm{c}}$. The spin lattice relaxation time $T_{1}$ of deuterium in $\mathrm{Mg}_{0.65} \mathrm{Ti}_{0.35} \mathrm{D}_{1.12}{ }^{(\mathrm{e})}$ decreases from $6.2 \mathrm{~s}$ at $280 \mathrm{~K}$ to $2.0 \mathrm{~s}$ at $355 \mathrm{~K}$ (Figure 6d) showing an Arrhenius temperature dependence with an activation energy of $13.6 \mathrm{~kJ} \mathrm{~mol}^{-1}$. This indicates that the deuterium mobility is relatively slow on the NMR frequency scale $\left(\omega_{0} \tau_{\mathrm{c}}>>1\right)$ as is consistent with the timescale of the hydrogen $\left({ }^{1} \mathrm{H}\right)$ mobility in the related $\mathrm{Mg}_{0.65} \mathrm{Sc}_{0.35} \mathrm{H}_{x} \cdot{ }^{[13]}$ The comparable temperature dependence of $\tau_{\mathrm{c}}$ and $\tau_{\mathrm{ex}}$ in our present study of $\mathrm{Mg}_{0.65} \mathrm{Ti}_{0.35} \mathrm{D}_{1.12}{ }^{(\mathrm{e})}$ suggests that the mobility underlying the $T_{1}$ relaxation and the Exsy correlation are related. A possible explanation is that $\tau_{\mathrm{c}}$ reflects the hopping of the deuterium atoms between neighboring sites within the Mg-rich and Ti-rich nanodomains, whereas $\tau_{\mathrm{ex}}$ reflects the (longer) average time it takes for deuterium to diffuse in multiple steps from sites within $\mathrm{Mg}$ rich nanodomains across the Mg-Ti interphase to sites within Tirich nanodomains, and vice versa.

In summary, although thin-film electrodes are scientifically interesting, bulk powders are more favorable for large-scale practical applications. Ball-milled Mg-Ti alloy powders do not undergo phase segregation during electrochemical loading at low temperatures, whereas gas-phase loading at the required elevated temperatures induces the alloys to phase segregate. 2D and 1D Exsy shows that Mg-rich and Ti-rich nanodomains in $\mathrm{Mg}_{0.65} \mathrm{Ti}_{0.35} \mathrm{D}_{1.12}$ (e) are closely connected. Therefore electrochemical hydrogenation at room temperature is an excellent alternative to hydrogenate metastable alloys, which phase segregate at the elevated temperatures required for gas-phase hydrogenation. These economically feasible ball-milled metastable $\mathrm{Mg}$-Ti alloy powders are therefore interesting to be applied in next generation of light-weight rechargeable Nickel Metal Hydride batteries.

\section{Supporting Information}

Supporting Information is available from the Wiley Online Library or from the author.

\section{Acknowledgements}

This research work in TU/e was financially supported by the Dutch Science foundation (NWO) as part of the Sustainable Hydrogen program of Advanced Chemical technologies for sustainability (ACTS). The authors would like to take this opportunity to thank their funding agency for supporting this research activity.

Received: May 29, 2013

Revised: July 8, 2013

Published online: September 1, 2013

[1] M. Momirlan, T. N. Veziroglu, Int. J. Hydrogen Energy 2005, 30, 795.

[2] L. Schlapbach, A. Züttel, Nature 2001, 414, 353.

[3] D. K. Ross, Vacuum 2006, 80, 1084.

[4] A. Züttel, Mater. Today 2003, 6, 24.

[5] A. Züttel, A. Borgschulte, L. Schlapbach, Hydrogen as A Future Energy Carrier, Wiley-VCH Verlag $\mathrm{GmbH} \&$ Co. KGaA, Weinheim, Germany 2008.

[6] P. Selvam, B. Viswanathan, C. S. Swamy, V. Srinivasan, Int. J. Hydrogen Energy 1986, 11, 169.

[7] P. E. de Jongh, Nat. Mater. 2011, 10, 265.

[8] H. G. Schimmel, J. Huot, L. C. Chapon, F. D. Tichelaar, F. M. Mulder, J. Am. Chem. Soc. 2005, 127, 14348.

[9] R. A. H. Niessen, P. H. L. Notten, Electrochem. Solid State Lett. 2005, 8, A534.

[10] Er. Süleyman, D. Tiwari, G. A. de Wijs, G. Brocks, Phys. Rev. B 2009, 79, 024105.

[11] R. A. H. Niessen, P. H. L. Notten, J. Alloy Compd. 2005, 404-406, 457.

[12] W. P. Kalisvaart, R. A. H. Niessen, P. H. L. Notten, J. Alloy Compd. 2006, 417, 280.

[13] M. S. Conradi, M. P. Mendenhall, T. M. Ivancic, E. A. Carl, C. D. Browning, P. H. L. Notten, W. P. Kalisvaart, P. C. M. M. Magusin, R. C. Bowman, S. Hwang, N. L. Adolphi, J. Alloy Compd. 2007, 446447, 499

[14] J. Murray, Bull. Alloy Phase Diagr. 1986, 7, 245.

[15] F. R. de Boer, R. Boom, W. C. M. Mattens, A. R. Miedema, A. K. Niessen, Cohesion in Metals: Transition Metal Alloys, NorthHolland, Amsterdam, 1988. 
[16] D. M. Borsa, R. Gremaud, A. Baldi, H. Schreuders, J. H. Rector, B. Kooi, P. Vermeulen, P. H. L. Notten, B. Dam, R. Griessen, Phys. Rev. B 2007, 75, 205408.

[17] T. Mitchell, S. Diplas, P. Tsakiropoulos, J. F. Watts, J. A. D. Matthew, Philos. Mag. A 2002, 82, 841.

[18] X. Tan, L. Wang, C. M. B. Holt, B. Zahiri, M. Eikerling, D. Mitlin, Phys. Chem. Chem. Phys. 2012, 14, 10904.

[19] P. Vermeulen, R. A. H. Niessen, P. H. L. Notten, Electrochem. Commun. 2006, 8, 27.

[20] G. Liang, R. Schulz, J. Mat. Sci. 2003, 38, 1179.

[21] S. Rousselot, M. P. Bichat, D. Guay, L. Roué, J. Power Sources 2008, $175,621$.

[22] J. Huot, D. B. Ravnsbæk, J. Zhang, F. Cuevas, M. Latroche, T. R. Jensen, Prog. Mater. Sci. 2013, 58, 30.

[23] S. Srinivasan, P. C. M. M. Magusin, W. P. Kalisvaart, P. H. L. Notten, F. Cuevas, M. Latroche, R. A. van Santen, Phys. Rev. B 2010, 81, 054107.

[24] W. P. Kalisvaart, C. T. Harrower, J. Haagsma, B. Zahiri, E. J. Luber, C. Ophus, E. Poirier, H. Fritzsche, D. Mitlin, Int. J. Hydrogen Energy 2010, 35, 2091
[25] P. Vermeulen, H. J. Wondergem, P. C. J. Graat, D. M. Borsa, H. Schreuders, B. Dam, R. Griessen, P. H. L. Notten, J. Mater. Chem. 2008, 18, 3680.

[26] N. L. Adolphi, J. J. Balbach, M. S. Conradi, J. T. Market, R. M. Cotts, P. Vajda, Phys. Rev. B 1996, 53, 15054.

[27] N. L. Adolphi, S. Badola, L. A. Browder, R. C. Bowman Jr., Phys. Rev. B 2001, 65, 024301.

[28] P. H. L. Notten, Curr. Opin. Solid State Methods 1999, 4, 5.

[29] S. Rousselot, A. Gazeau, D. Guay, L. Roué, Electrochim. Acta 2010, 55,611 .

[30] D. Kyoi, T. Sato, E. Rönnebro, N. Kitamura, A. Ueda, M. Ito, S. Katsuyama, S. Hara, D. Noréus, T. Sakai, J. Alloy Compd. 2004, $372,213$.

[31] S. Srinivasan, P. C. M. M. Magusin, R. A. van Santen, P. H. L. Notten, H. Schreuders, B. Dam, J. Phys. Chem. C 2011, 115, 288.

[32] P. C. M. M. Magusin, W. P. Kalisvaart, P. H. L. Notten, R. A. van Santen, Chem. Phys. Lett. 2008, 456, 55.

[33] E. Fukushima, S. B. W. Roeder, Experimental Pulse NMR. A Nuts and Bolts Approach, Addison-Wesley Publishing Company, Boston, MA 1981. 